\title{
Impact of the insurance costs on the competitiveness of food industry enterprises of Ukraine in the context of the food market security
}

\author{
Lada Shirinyan, Mykhailo Arych \\ National University of food Technologies, Kyiv, Ukraine
}

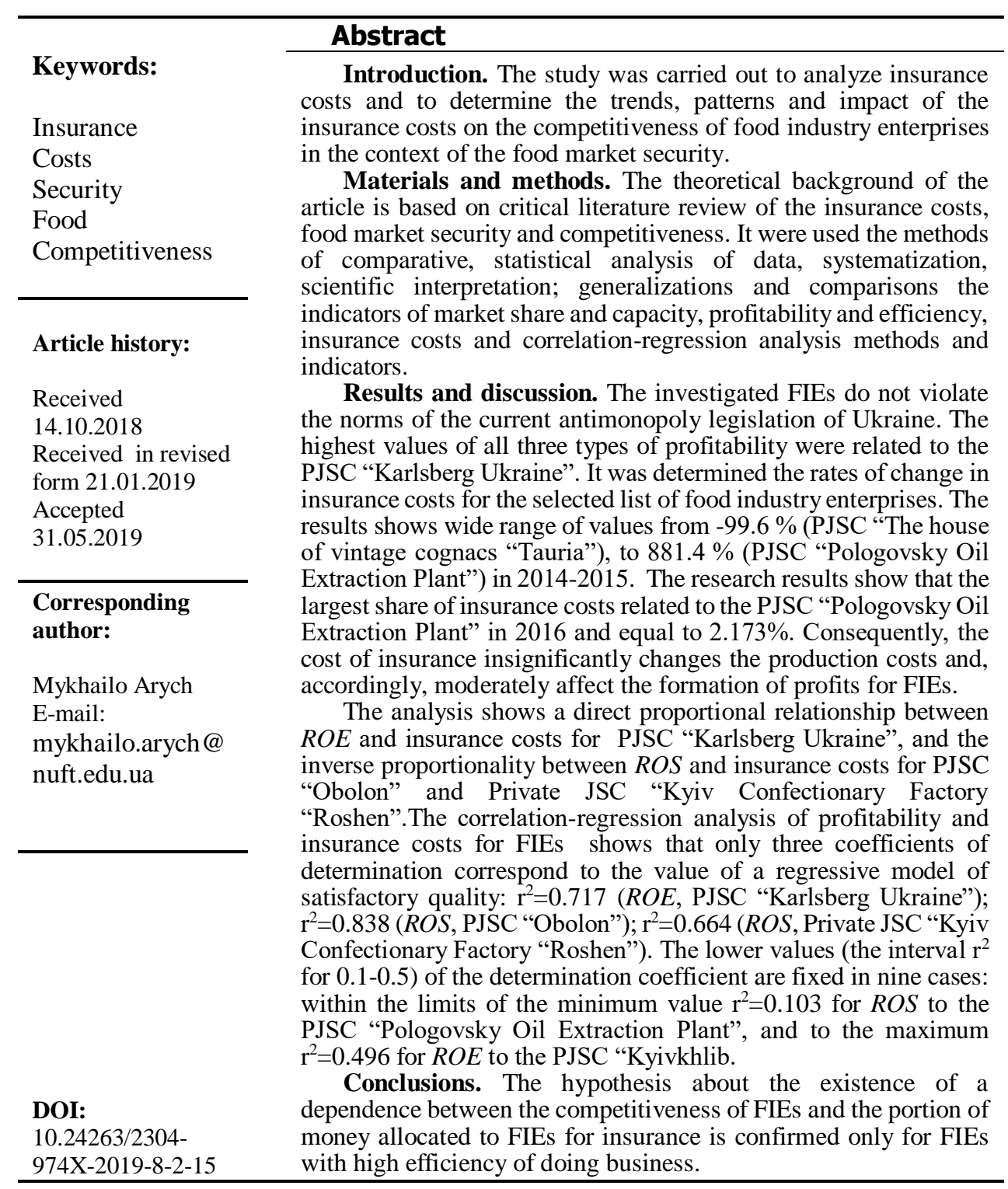




\section{Introduction}

The food industry is the leading industry in the agro-industrial complex of Ukraine, as evidenced by data on consumption volumes of its products in the markets [23, 29]. At the same time, food industry enterprises (further referred to as FIEs), which, like most industrial enterprises, may be exposed to risks that could significantly impair financial performance [26-29]. From these positions, the appropriateness of insurance becomes evident, as it serves as a necessary and effective tool for protecting against risks and contributes to increasing the competitiveness of the enterprise [38]. In addition, it should also be noted that the current trends in international experience in the functioning of agro-industrial enterprises (including FIEs) in agricultural sector (ACS), show the important role of insurance as an element of security in the food market [45-47]. The nature of such interaction will be investigated in the presented study.

Issues of the impact of insurance and the effectiveness of the FIEs and ACS are discussed by different foreign researchers. Akinrinola O.O. and Okunola A.M. (2014) have studied the effect of agricultural insurance scheme on agricultural production in Ondo state (Nigeria). Scientists have determined that there may be an increase in the level of investment of farms after participating in insurance. This is due to the availability of agricultural loans secured by insurance coverage. Farmers also increased the size of their farms and output volumes [1]. Spörri M., Baráth L., Bokusheva R. and Fertö I.(2012) have investigated the impact of crop insurance on the productivity of Hungarian farms and revealed the negative impact of insurance on economic indicators of economic profit, productivity of labor and productivity of land [2].

Juan H. et al.(2016) proposed a theoretical model that counts several features of the insurance program of the crop, taking into account the empirical parameter of interest. The model also forecasts the condition of positive impact of insurance on the use of enterprise resources, if preliminary estimation of efficiency will be carried out [3].

Also, special attention among foreign studies deserves the following researchers: Zhao $Y$. and Preckel P. (2016) with an empirical analysis of the effect of crop insurance on farmers' income" [4]; Kim Y., Pendell D.L. and Yu J. (2018) with effects of crop insurance on farm disinvestment and exit decisions [5]; Jisang Yua J. and Sumnerb D.A. (2017) with effects of subsidized crop insurance on crop choices [6]; Bachev H. (2012) with risk management in the ACS [7]; Lorant A. and Farkas M.F. (2015) with risk management in the ACS with special attention to insurance [8] and many others.

Most of Ukrainian researchers assess the competitiveness of the national FIEs and ACS of Ukraine without taking into account insurance. Baeva V.V. (2015.) notes that at present there is no generally accepted method for assessing competitiveness, but all methodological approaches can be divided into quantitative and qualitative ones [9].

According to Pylypenko V.V. and Pylypenko N.M. (2016) there exist three groups of activity characteristics: agricultural enterprise (product competitiveness, market environment and financial and economic status) and one needs expert judgment for weighting factors to evaluate effective competition [10].

Legeza D.G. (2011) focuses on methods of assessing the competitiveness of agricultural products through twelve indicators, including the proportion of material costs, merchantability, profit, profitability, etc. [11].

Cherednichenko O.O. (2013.) investigates the evaluation of the competitiveness of dairy agricultural enterprises on the basis of three approaches: 1) the traditional method of assessing the competitiveness of goods by calculating unit and group indicators; 2) marketing approach taking into account the consumer's requirements for price and quality of goods and 
factors that determine the competitiveness of all marketing activities of the enterprise; 3 ) production approach, based on the assessment of the profitability of sales of a particular product and its market share [12].

Tycholyz L.S. (2013.) generalizes methods of assessing the competitiveness of agricultural enterprises in nine groups [13].

The analysis of the development of the FIEs of Ukraine is the object of research of many Ukrainian scientists from different positions as follow below.

Irytytsheva I.O. (2012) pays attention on the necessity of developing a qualitative plan [14], Vasilchenko K.G. (2013) defines the prospects of innovation in the food industry [5], Kvasko A.V. (2017) notes that the problem of choosing a universal indicator and factors of competitiveness remains unresolved [16], Buracek I.V. and Bilenchuk O.O. (2016) analyze the competitiveness of the enterprise competitiveness of the subject of economic activity [17], Shwed T.V and Bila I.S. (2017) group methods of assessing the competitiveness of enterprises [18]. As far as we know, the analysis of the impact of the cost of insurance on the competitiveness of FIEs is still beyond the attention of researchers. This gap is under the attention in presented study.

Our investigation is also related to the food market security. Isaboke et al. (2016) described the effect of weather index based micro-insurance on food security status of smallholders, and find that a positive impact on food security is associated with the uptake of index insurance [45]. Mârzaa et al. (2015) suggest that insurance alone cannot provide food security. It can make a big impact in raising awareness of the importance of risk reducing and encouraging investments in increasing the ACS development 46]. According to the report of the Agricultural Insurance Conference (Berlin, 2014) agricultural insurance should be seen as one component of the ACS and it is related to food security [47].

We aim to analyze insurance costs, performance indicators and competitiveness of food industry enterprises in Ukraine and to identify trends and patterns that may exist on the market and relationships between insurance costs, competitiveness of the FIEs and food market security.

To achieve this goal it is necessary to accomplish the following tasks:

- to systematize data about the cost of insurance for FIEs through financial reporting, official private and public Internet resources;

- promote and test hypotheses regarding the interaction link between competitiveness of the FIEs and amount of money allocated for insurance, and validate the hypotheses regarding the FIEs propensity to insurance with a higher competitiveness.

\section{Materials and methods}

Materials. The theoretical background of the article is based on competitiveness theories explaining the ability of the market subjects to act on a par with competitors that present there [19-20]. The information base of the study was financial reporting, private and official public Internet resources, information from the official website of the Agency for the Development of the Stock Market Infrastructure of Ukraine [21] and State Statistics Service of Ukraine [22]. In order to create a database of insurance companies' expenses for the years 2013-2017, data from more than 500 FIEs of Ukraine was analyzed, however, reliable information was collected about only 13 FIEs. The search for FIEs was carried out according to the code of the Unified State Register of Enterprises and Organizations of Ukraine [49$50]$. 
Methods. With the aim to determine the trends, patterns and impact of the insurance costs on the competitiveness of food industry enterprises in the context of the food market security, we implemented the critical literature review, content, comparative [1-5], statistical analysis of data [6-9, 11], systematization and synthesis [12, 14-18], scientific interpretation and scientific discourse analysis methods [24-31]. Systematization and critical literature review methods were used to prepare a theoretical background for our research study [1-18, 20-49].

The methods of comparative and statistical analysis of data was used in the study of data from the Agency for the Development of the Stock Market Infrastructure of Ukraine [21] and from the State Statistics Service of Ukraine [22]. During the processing such data, it turned out that information on insurance costs for FIEs is not provided or such information is provided only for few years of the proposed study period 2013-2017. Due to the data of Agency for the Development of the Stock Market Infrastructure of Ukraine, we have determined the insurance costs for each year in the find tab "Notes to the Financial Statements, prepared in accordance with international financial reporting standards" [21-22]. In most cases that indicator is designated as "Insurance" or "Insurance costs", etc.

The results of the studies the impact of the insurance costs on the competitiveness of food industry enterprises in the context of the food market security are obtained through the use of grouping methods [1-3], generalizations and comparisons the indicators of market share and capacity $[8,10]$, profitability and efficiency, insurance costs and correlationregression analysis methods and indicators [4-17].

\section{Results and discussion}

Considering the competitiveness of FIEs as a factor in successful business development, it is necessary to determine the definitions. We consider the definition of "competitiveness" as a complex comparative characteristic, which determines the degree of advantage of a set of indices of one FIE over the aggregate of other FIEs indicators and characterizes the ability to compete. The competitiveness of FIEs is achieved in the presence of rivalry in order to expand and win the market in the struggle for the consumer, for the sake of victory of competitors and profits [19]. The assessment of FIEs competitiveness can be achieved by comparing various aspects and the most significant indicators of FIEs activity, including indicators such as performance, market share, concentration, etc.

It is also worth noting that insurance for FIEs as a prerequisite for ensuring competitiveness, also contributes to ensuring security in the food market.

According the approach by Porter M., "competitiveness" of the market subjects relations - it is his ability to act on a par with competitors that present there [20]. Consequently, in order to assess competitiveness, it is necessary to identify competitors, collect the information about market capacities and benefits.

The general factors that determine the competitiveness of FIEs and the needs of food products industry, researchers traditionally include: the size of cash incomes, the volume and range of food products, the level of saturation of the market by certain types of products, the level of retail prices for goods; the number and age structure of the population, its national habits, the level of trade organization [15]. The list below does not cover FIEs expenses for insurance. That is why, according to this research, we are starting a new direction of research and will carry out an analysis of insurance costs, indicators of efficiency and competitiveness of the FIEs of Ukraine. 
Our scientific first hypothesis is formulated as follows: "the main subjects of the food industry market with a higher competitiveness are more prone to insurance". The second hypothesis is as follows: "there is a relationship between the competitiveness of the FIEs and the portion of the money allocated to the insurance business".

\section{Market share and capacity}

For completeness of the description of selected FIEs, we will investigate the contributions of such FIEs to the food industry of Ukraine and the level of influence on the formation of gross domestic product (GDP) during 2013-2017. For further analysis, we propose the indicators of concentration and capacity of the enterprise.

An analysis of the situation of the company in the market is calculated by using a specific share of the entity, which we defined as net income (NI) from the main operating activity:

$$
\mathrm{C}_{1}=100 \% \mathrm{NI}_{1} / \mathrm{NI},
$$

where $\mathrm{C}_{1}$ - shares of the entity in the net income of all enterprises in the market (in \%), $\mathrm{NI}_{1}$ - net income of enterprise (UAH), NI - net income of all enterprises in the market (in our case, the total net income on the food industry market of Ukraine). Net income of enterprise $\left(\mathrm{NI}_{1}\right)$ is determined by the line 2000 form 2 of the report on the financial results of the FIEs and determines the net proceeds from the sale.

To determine the degree of monopolization in the market use the so-called concentration factor $C R$, which is determined by adding the shares of individual players: for example, $C R_{2}=\mathrm{K}_{1}+\mathrm{K}_{2}$ for the first two market subjects, $C R_{3}$ for the first three market subjects etc., which are the most successful market participants. The current antimonopoly legislation of Ukraine defines the criteria for monopolization of the market when: $\mathrm{CR}_{1}>35 \% ; C R_{3}>50 \%$; $C R_{5}>70 \%$ [19].

The next indicator will be the capacity $(\eta)$ of the enterprise, which we determine with the share of net income of the enterprise in the formation of GDP of Ukraine by the formula:

$$
\eta_{1}=100 \% \mathrm{NI}_{1} / \text { GDP. }
$$

where $\eta_{1}$ - capacity of one enterprise in percent, GDP - the value of the gross domestic product of Ukraine (UAH).

As we can see, the investigated FIEs do not violate the norms of the current antimonopoly legislation of Ukraine.

Based on the data of the table 1, it has been determined that among the list of enterprises represented the largest share in both the food industry and GDP of Ukraine is related to the PJSC "Karlsberg Ukraine", the average arithmetic mean of the corresponding values of the share for the study period 2013-2017 is equal to $1.173 \%$ and $0.220 \%$. At the same time, the smallest similar values are characteristic for PJSC "Sumy food products factory" $-0.028 \%$ and $0.005 \%$.

We will examine the following indicators for sample enterprises (table 1). 
Indicators of the share and capacity of the FIEs

Table 1

\begin{tabular}{|c|c|c|c|c|c|c|}
\hline \multirow{2}{*}{ Enterprise } & \multirow{2}{*}{$\begin{array}{c}\text { Indicators } \\
K_{1} \text { and } \eta_{1}\end{array}$} & \multicolumn{5}{|c|}{ Values of indexes by years, \% } \\
\hline & & 2013 & 2014 & 2015 & 2016 & 2017 \\
\hline \multirow{2}{*}{$\begin{array}{l}\text { PJSC "Karlsberg } \\
\text { Ukraine" }\end{array}$} & $\mathrm{K}_{1}$ & 1.371 & 1.145 & 1.151 & 1.103 & 1.096 \\
\hline & $\eta_{1}$ & 0.237 & 0.218 & 0.230 & 0.214 & 0.202 \\
\hline \multirow{2}{*}{ PJSC “Obolon” } & $\mathrm{K}_{1}$ & 1.530 & 1.055 & 0.915 & 0.762 & 0.905 \\
\hline & $\eta_{1}$ & 0.265 & 0.201 & 0.183 & 0.148 & 0.166 \\
\hline \multirow{2}{*}{ PJSC "Kyivkhlib” } & $\mathrm{K}_{1}$ & 0.744 & 0.560 & 0.493 & 0.601 & 0.415 \\
\hline & $\eta_{1}$ & 0.129 & 0.107 & 0.099 & 0.116 & 0.076 \\
\hline \multirow{2}{*}{$\begin{array}{l}\text { PJSC "Pologovsky } \\
\text { Oil Extraction Plant" }\end{array}$} & $\mathrm{K}_{1}$ & 0.440 & 0.535 & 0.669 & 0.535 & 0.568 \\
\hline & $\eta_{1}$ & 0.076 & 0.102 & 0.134 & 0.104 & 0.104 \\
\hline \multirow{2}{*}{$\begin{array}{l}\text { Private JSC "APK- } \\
\text { INVEST" }\end{array}$} & $\mathrm{K}_{1}$ & 0.396 & 0.455 & 0.464 & 0.418 & 0.486 \\
\hline & $\eta_{1}$ & 0.069 & 0.087 & 0.093 & 0.081 & 0.089 \\
\hline \multirow{2}{*}{$\begin{array}{l}\text { PJSC "Zhytomyr } \\
\text { Butter Factory” }\end{array}$} & $\mathrm{K}_{1}$ & 0.396 & 0.392 & 0.384 & 0.384 & 0.355 \\
\hline & $\eta_{1}$ & 0.068 & 0.075 & 0.077 & 0.074 & 0.065 \\
\hline \multirow{2}{*}{$\begin{array}{l}\text { PJSC "Kharkiv } \\
\text { Biscuit Factory" }\end{array}$} & $\mathrm{K}_{1}$ & 0.342 & 0.338 & 0.396 & 0.403 & 0.369 \\
\hline & $\eta_{1}$ & 0.059 & 0.064 & 0.079 & 0.078 & 0.068 \\
\hline \multirow{2}{*}{$\begin{array}{l}\text { PJSC "Dniprovsky } \\
\text { starch flour combine" }\end{array}$} & $\mathrm{K}_{1}$ & 0.149 & 0.146 & 0.156 & 0.117 & 0.139 \\
\hline & $\eta_{1}$ & 0.026 & 0.028 & 0.031 & 0.023 & 0.025 \\
\hline \multirow{2}{*}{$\begin{array}{l}\text { Private JSC "Kyiv } \\
\text { Confectionary Factory } \\
\text { "Roshen" }\end{array}$} & $\mathrm{K}_{1}$ & 0.196 & 0.097 & 0.063 & 0.050 & 0.047 \\
\hline & $\eta_{1}$ & 0.034 & 0.019 & 0.013 & 0.010 & 0.009 \\
\hline \multirow{2}{*}{$\begin{array}{l}\text { PJSC "The house of } \\
\text { vintage cognacs } \\
\text { "Tauria" }\end{array}$} & $\mathrm{K}_{1}$ & 0.076 & 0.150 & 0.181 & 0.152 & 0.141 \\
\hline & $\eta_{1}$ & 0.013 & 0.029 & 0.036 & 0.030 & 0.026 \\
\hline \multirow{2}{*}{$\begin{array}{l}\text { PJSC } \\
\text { "Confectionery } \\
\text { Factory } \\
\text { "Kharkivyanka" }\end{array}$} & $\mathrm{K}_{1}$ & 0.066 & 0.062 & 0.046 & 0.050 & 0.057 \\
\hline & $\eta_{1}$ & 0.011 & 0.012 & 0.009 & 0.010 & 0.010 \\
\hline \multirow{2}{*}{$\begin{array}{l}\text { PJSC "Kremenchug } \\
\text { confectionery } \\
\text { factory" }\end{array}$} & $\mathrm{K}_{1}$ & 0.062 & 0.040 & 0.045 & 0.040 & 0.040 \\
\hline & $\eta_{1}$ & 0.011 & 0.008 & 0.009 & 0.008 & 0.007 \\
\hline \multirow{2}{*}{$\begin{array}{l}\text { PJSC "Sumy food } \\
\text { products factory" }\end{array}$} & $\mathrm{K}_{1}$ & 0.003 & 0.031 & 0.038 & 0.032 & 0.034 \\
\hline & $\eta_{1}$ & 0.001 & 0.006 & 0.008 & 0.006 & 0.006 \\
\hline
\end{tabular}

* Author's calculations based on official data [21;22]. 


\section{Profitability and efficiency}

Speaking about the effectiveness of the FIEs, it should be noted that efficiency characterizes economic results for each unit cost. The most commonly used measure of effectiveness is ROA (return on assets), which is determined by the formula:

$$
R O A=100 \% \mathrm{NP} / \mathrm{A} .
$$

where NP - net profit of the FIEs. Net profit is a net financial result: the profit determined by line 2350 for a positive result and line 2355 for the event of losses.

The efficiency of FIEs is provided under the following conditions:

$$
R O A \rightarrow \max , R O A>0 .
$$

Another indicator of efficiency can be the rate of return on equity $R O E$ (return on equity), which we define by the formula:

$$
R O E=100 \% \mathrm{NP} / \mathrm{E} .
$$

The value of $E$ is equity, which is determined by line 1495 of form 1 of the balance sheet of the financial statements of the enterprise.

Under the following conditions: $R O E>10 \%$, investments can be considered successful.

It is also worth considering the ROS (return on sales) profitability based on net income:

$$
R O S=100 \% \mathrm{NP} / \mathrm{NI}_{1} .
$$

where $R O S$ - return on sales, $\mathrm{NI}_{1}$ - income of the sales.

Let's move on to assess the effectiveness of the FIEs according to the profitability indicators (table 2).

During the study period 2013-2017, among the selected list of food industry enterprises, the highest values of all three types of profitability were related to the PJSC "Karlsberg Ukraine". At the same time, for many investigated enterprises (PJSC "Obolon", PJSC "Kyivkhlib", PJSC "Sumy food products factory", PJSC "Pologovsky Oil Extraction Plant" and PJSC "Kremenchug confectionery factory") these indicators for individual periods could be regarded as indicators of loss.

The low value of the profitability of the FIEs in Ukraine the researchers explain by the problems of the industry itself, as well as the economic and political situation in the country [14; 23; 24]. In order to improve the situation and increase the competitiveness of the FIEs, various measures are proposed, among which: the use of advanced production technologies; improvement of the qualification base of employees; improvement of the infrastructure of storage and distribution of products of food producers; strengthening of quality control and product safety [25]. 
Profitability indicators of the FIEs in Ukraine*

Table 2

\begin{tabular}{|c|c|c|c|c|c|c|}
\hline \multirow{2}{*}{ Enterprise } & \multirow{2}{*}{ Indicators } & \multicolumn{5}{|c|}{ Calculated values of profitability by years, \% } \\
\hline & & 2013 & 2014 & 2015 & 2016 & 2017 \\
\hline \multirow{3}{*}{$\begin{array}{l}\text { PJSC "Karlsberg } \\
\text { Ukraine" }\end{array}$} & $R O A$ & 17.05 & 21.05 & 20.49 & 18.78 & 20.72 \\
\hline & $R O E$ & 21.17 & 26.71 & 27.28 & 30.03 & 35.77 \\
\hline & $R O S$ & 45.49 & 42.03 & 36.13 & 40.67 & 42.12 \\
\hline \multirow{3}{*}{ PJSC “Obolon” } & $R O A$ & 5.38 & -18.30 & -12.54 & -4.65 & 2.61 \\
\hline & $R O E$ & 16.10 & -74.40 & $\begin{array}{c}- \\
159.32\end{array}$ & -26.73 & 7.34 \\
\hline & $R O S$ & 38.04 & 36.40 & 34.42 & 32.51 & 28.17 \\
\hline \multirow{3}{*}{ PJSC "Kyivkhlib" } & $R O A$ & 5.88 & -5.07 & -5.38 & 2.88 & 1.96 \\
\hline & $R O E$ & 14.37 & -11.70 & -20.13 & 13.55 & 9.58 \\
\hline & $R O S$ & 23.02 & 24.27 & 26.94 & 24.92 & 24.25 \\
\hline \multirow{3}{*}{$\begin{array}{l}\text { PJSC "Pologovsky } \\
\text { Oil Extraction } \\
\text { Plant" }\end{array}$} & $R O A$ & 3.56 & -1.38 & 12.90 & -1.22 & 0.99 \\
\hline & $R O E$ & 13.91 & -4.42 & 38.84 & -4.24 & 4.32 \\
\hline & $R O S$ & 12.17 & 25.18 & 16.88 & 13.07 & 9.46 \\
\hline \multirow{3}{*}{$\begin{array}{l}\text { Private JSC "APK- } \\
\text { INVEST" }\end{array}$} & $R O A$ & 6.54 & -3.72 & 2.17 & 6.60 & 18.56 \\
\hline & $R O E$ & 33.80 & -19.65 & 10.39 & 17.21 & 33.58 \\
\hline & $R O S$ & 17.64 & -7.48 & 3.54 & 13.07 & 33.37 \\
\hline \multirow{3}{*}{$\begin{array}{l}\text { PJSC "Zhytomyr } \\
\text { Butter Factory" }\end{array}$} & $R O A$ & 10.00 & 13.20 & 14.71 & 16.88 & 10.94 \\
\hline & $R O E$ & 12.97 & 16.47 & 18.23 & 21.41 & 16.27 \\
\hline & $R O S$ & 25.63 & 24.03 & 24.03 & 25.25 & 26.06 \\
\hline \multirow{3}{*}{$\begin{array}{l}\text { PJSC "Kharkiv } \\
\text { Biscuit Factory" }\end{array}$} & $R O A$ & 6.55 & 20.89 & 19.96 & 12.57 & 13.45 \\
\hline & $R O E$ & 7.33 & 22.37 & 22.01 & 13.91 & 14.83 \\
\hline & $R O S$ & 14.78 & 17.81 & 15.06 & 13.34 & 14.72 \\
\hline \multirow{3}{*}{$\begin{array}{l}\text { PJSC "Dniprovsky } \\
\text { starch flour } \\
\text { combine" }\end{array}$} & $R O A$ & 1.97 & 0.37 & 4.59 & -1.07 & 2.41 \\
\hline & $R O E$ & 3.17 & 0.66 & 8.78 & -2.55 & 8.06 \\
\hline & $R O S$ & 3.18 & 0.58 & 5.82 & -2.00 & 4.62 \\
\hline \multirow{3}{*}{$\begin{array}{l}\text { Private JSC "Kyiv } \\
\text { Confectionary } \\
\text { Factory "Roshen" }\end{array}$} & $R O A$ & 0.47 & 4.35 & 1.48 & 0.57 & 0.38 \\
\hline & $R O E$ & 0.81 & 6.94 & 2.10 & 0.74 & 0.52 \\
\hline & $R O S$ & 8.37 & 12.97 & 13.85 & 12.08 & 11.88 \\
\hline \multirow{3}{*}{$\begin{array}{l}\text { PJSC "The house of } \\
\text { vintage cognacs } \\
\text { "Tauria" }\end{array}$} & $R O A$ & 0.23 & -6.01 & 17.01 & 3.61 & 1.42 \\
\hline & $R O E$ & 0.53 & -16.08 & 47.96 & 14.45 & 5.75 \\
\hline & $R O S$ & 72.66 & 47.20 & 51.57 & 19.25 & 14.37 \\
\hline \multirow{3}{*}{$\begin{array}{l}\text { PJSC "Confectionery } \\
\text { Factory } \\
\text { "Kharkivyanka" }\end{array}$} & $R O A$ & 1.26 & 3.38 & 2.09 & 1.94 & 8.23 \\
\hline & $R O E$ & 1.99 & 5.14 & 4.44 & 5.08 & 19.66 \\
\hline & $R O S$ & 1.30 & 3.13 & 2.88 & 2.75 & 9.03 \\
\hline \multirow{3}{*}{$\begin{array}{l}\text { PJSC "Kremenchug } \\
\text { confectionery } \\
\text { factory" }\end{array}$} & $R O A$ & -1.29 & -2.86 & 0.92 & -0.19 & 0.00 \\
\hline & $R O E$ & -3.01 & -6.18 & 2.60 & -0.81 & 0.01 \\
\hline & $R O S$ & 10.40 & 6.08 & 10.60 & 8.63 & 8.95 \\
\hline \multirow{3}{*}{$\begin{array}{l}\text { PJSC "Sumy food } \\
\text { products factory" }\end{array}$} & $R O A$ & -4.26 & 7.00 & -14.43 & 0.18 & 0.95 \\
\hline & $R O E$ & -6.66 & 15.83 & -38.74 & 0.32 & 1.91 \\
\hline & $R O S$ & 11.59 & 8.45 & 3.83 & 4.01 & 8.34 \\
\hline
\end{tabular}

* Author's calculations based on official data [21]. 


\section{Insurance costs}

The research of the FIEs and theirs insurance costs $\left(\mathrm{IC}_{1}\right)$ was conducted for checking of the first hypothesis of our research (table 3).

Data of the Table 3 characterize the dynamics of insurance costs for the FIEs of Ukraine. It should be noted that, in accordance with the conditions for the presentation of this information in the financial statements of the entities presented, one can distinguish the following features:

- Firstly, some companies data on insurance costs separate the individual components and indicate it in the reporting: PJSC "Kyivkhlib" (two types: the cost of property insurance and insurance costs are included in "Expenses on sales");

- Secondly, two out of the thirteen investigated companies made public health insurance data for their employees PJSC "Kremenchug confectionery factory" and Private JSC "Kyiv Confectionary Factory "Roshen").

Insurance costs for food industry enterprises in Ukraine*

Table 3

\begin{tabular}{|l|c|c|c|c|c|}
\hline \multirow{2}{*}{ Name of the FIE } & \multicolumn{5}{|c|}{ Insurance costs, thousand UAH } \\
\cline { 2 - 6 } & $\mathbf{2 0 1 3}$ & $\mathbf{2 0 1 4}$ & $\mathbf{2 0 1 5}$ & $\mathbf{2 0 1 6}$ & $\mathbf{2 0 1 7}$ \\
\hline PJSC "Karlsberg Ukraine" & 6142 & 6190 & 7279 & 10248 & 10231 \\
\hline PJSC "Obolon" & 2055 & 1902 & 2188 & 2210 & 2528 \\
\hline PJSC "Kyivkhlib" & 241 & 341 & 340 & 122 & 319 \\
\hline $\begin{array}{l}\text { PJSC "Pologovsky Oil } \\
\text { Extraction Plant" }\end{array}$ & 4798.5 & 3799.8 & 37290.2 & 46738 & 20863 \\
\hline Private JSC “APK-INVEST" & 1151.8 & 1639.7 & 2200.1 & 2441.7 & 2283.4 \\
\hline $\begin{array}{l}\text { PJSC "Zhytomyr Butter } \\
\text { Factory" }\end{array}$ & 385 & 305 & 593 & 547 & 677 \\
\hline $\begin{array}{l}\text { PJSC "Kharkiv Biscuit } \\
\text { Factory" }\end{array}$ & 182 & 160 & 206 & 185 & 224 \\
\hline $\begin{array}{l}\text { PJSC "Dniprovsky starch } \\
\text { flour combine" }\end{array}$ & no data & no data & 456 & 930 & 1055 \\
\hline $\begin{array}{l}\text { Private JSC "Kyiv } \\
\text { Confectionary Factory } \\
\text { "Roshen" }\end{array}$ & 2071 & 1250 & 589 & 582 & 677 \\
\hline $\begin{array}{l}\text { PJSC "The house of vintage } \\
\text { cognacs "Tauria" }\end{array}$ & 298 & 267 & 47 & 292 & 54 \\
\hline $\begin{array}{l}\text { PJSC "Confectionery Factory } \\
\text { "Kharkivyanka" }\end{array}$ & no data & 69 & 79 & 61 & 70 \\
\hline $\begin{array}{l}\text { PJSC "Kremenchug } \\
\text { confectionery factory" }\end{array}$ & 1199 & 655 & 347 & 391 & 391 \\
\hline $\begin{array}{l}\text { PJSC "Sumy food products } \\
\text { factory" }\end{array}$ & 38 & 61 & 45 & 45 & 73 \\
\hline
\end{tabular}

* Author's calculations based on official data [21]. 
For a more detailed study of the cost of insurance, we will analyze the rate of their change in percentage over the years 2013-2017. The rate of change in insurance costs for the selected FIEs list shows results in a wide range of values: from -99.6 \% (PJSC "The house of vintage cognacs "Tauria"), to 881.4 \% (PJSC "Pologovsky Oil Extraction Plant") in 20142015. In this case, the calculated average arithmetic values of the rate of change in insurance costs during 2013-2017 years ranged from $-27.4 \%$ (PJSC "The house of vintage cognacs "Tauria", property insurance costs in other operating costs) and to $207.6 \%$ (PJSC "Pologovsky Oil Extraction Plant").

Insurance costs are an integral part of the entity's total costs, and therefore it would be expedient to analyze their share in total costs by the formula:

$$
S_{l}=100 \% \mathrm{IC}_{1} / \mathrm{PC}_{1} .
$$

where $S_{l}$ - share of insurance costs in total costs, $\mathrm{IC}_{1}$ - insurance costs, $\mathrm{PC}_{1}$ - production costs (costs of sold products). Insurance costs $\mathrm{IC}_{1}$ is determined in accordance with the notes to the financial statements, which was prepared in accordance with international financial reporting standards; the value of $\mathrm{PC}_{1}$ is determined by line 2050 forms 2 financial statements of the enterprise.

It is noteworthy that the cost of production shows the costs of preparation for production, marketing of products (direct material costs, direct labor costs, other direct costs, variable generic and permanent distributed production costs, etc.). Therefore, cost is the best indicator for determining the cost of an enterprise, but the list and composition of articles of cost is determined by the enterprise itself.

The relative share of the insurance costs in the cost of the selected for the study of FIEs of Ukraine is characterized by quite different values (table 4).

Among the selected list of food industry enterprises in Ukraine the largest insurance costs compared with production cost are related to the PJSC "Pologovsky Oil Extraction Plant", the maximum share of which insurance costs is $2.173 \%$ in 2016, thus in 2013-2017 the average value of this indicator is $1.08 \%$ of total production costs. The smallest values of the share of insurance costs in the total production costs per study period of 2013-2017 years are related to the PJSC "Kyivkhlib": from $0.007 \%$ in 2016, and to $0.027 \%$ in 2014.

In general, there is a small impact of the insurance cost on the total production costs of FIEs. The largest share of insurance costs related to the PJSC "Pologovsky Oil Extraction Plant" in 2016 and equal to $2.173 \%$. Consequently, the cost of insurance insignificantly changes the production costs and, accordingly, moderately affect the formation of profits for FIEs.

In the first place, the share of insurance costs in total production costs are PJSC "Pologovsky Oil Extraction Plant", PJSC "Karlsberg Ukraine", Private JSC "Kyiv Confectionary Factory "Roshen". These enterprises also have high profitability and efficiency, but there are others in the list in Table 2 . Thus, the analysis does not fully support the first hypothesis that "the main subjects of the food industry market with a higher competitiveness are more prone to insurance". 
Table 4

Share of insurance costs in the cost of sold products of the FIEs of Ukraine*

\begin{tabular}{|c|c|c|c|c|c|}
\hline \multirow{2}{*}{ Name of the FIE } & \multicolumn{5}{|c|}{ Percentage of insurance costs, \% } \\
\hline & 2013 & 2014 & 2015 & 2016 & 2017 \\
\hline PJSC "Karlsberg Ukraine" & 0.324 & 0.308 & 0.249 & 0.339 & 0.294 \\
\hline PJSC “Obolon” & 0.114 & 0.094 & 0.092 & 0.093 & 0.071 \\
\hline PJSC “Kyivkhlib” & 0.017 & 0.027 & 0.024 & 0.007 & 0.016 \\
\hline $\begin{array}{l}\text { PJSC "Pologovsky Oil } \\
\text { Extraction Plant" }\end{array}$ & 0.489 & 0.314 & 1.684 & 2.173 & 0.740 \\
\hline $\begin{array}{l}\text { Private JSC “APK- } \\
\text { INVEST” }\end{array}$ & 0.121 & 0.134 & 0.139 & 0.149 & 0.101 \\
\hline $\begin{array}{l}\text { PJSC "Zhytomyr Butter } \\
\text { Factory" }\end{array}$ & 0.052 & 0.034 & 0.051 & 0.041 & 0.047 \\
\hline $\begin{array}{l}\text { PJSC "Kharkiv Biscuit } \\
\text { Factory" }\end{array}$ & 0.025 & 0.019 & 0.015 & 0.011 & 0.013 \\
\hline $\begin{array}{l}\text { PJSC "Dniprovsky starch } \\
\text { flour combine" }\end{array}$ & no data & no data & 0.093 & 0.192 & 0.173 \\
\hline $\begin{array}{l}\text { Private JSC "Kyiv } \\
\text { Confectionary Factory } \\
\text { "Roshen" }\end{array}$ & 0.451 & 0.488 & 0.273 & 0.285 & 0.296 \\
\hline $\begin{array}{l}\text { PJSC "The house of vintage } \\
\text { cognacs "Tauria" }\end{array}$ & 0.563 & 0.111 & 0.013 & 0.051 & 0.008 \\
\hline $\begin{array}{l}\text { PJSC "Confectionery } \\
\text { Factory "Kharkivyanka" }\end{array}$ & no data & 0.040 & 0.048 & 0.030 & 0.025 \\
\hline $\begin{array}{l}\text { PJSC "Kremenchug } \\
\text { confectionery factory" }\end{array}$ & 0.851 & 0.582 & 0.216 & 0.233 & 0.197 \\
\hline $\begin{array}{l}\text { PJSC "Sumy food products } \\
\text { factory" }\end{array}$ & 0.044 & 0.828 & 0.031 & 0.032 & 0.043 \\
\hline
\end{tabular}

* Author's calculations based on official data [21].

\section{Correlation-regression analysis}

To test the hypotheses, we will investigate the insurance cost impact on performance and competitiveness of the FIEs. The hypothesis test was performed using a one-factor regression model. This is done by an argument variable $\mathrm{X}$ for insurance costs $\mathrm{IC}_{1}$ (table 3 ), but the target function of the analysis (dependent variable $\mathrm{Y}$ ) - profitability indicators $R O A$, $R O E, R O S$ (table 1). Equation of pair linear regression was constructed in the form of dependence $\mathrm{Y}=\mathrm{A}+\mathrm{BX}$. The corresponding calculations are given in Table 5 . 
Table 5

Indicators of correlation-regression analysis of profitability $(Y)$ and insurance costs $(X)$ for FIEs of Ukraine for 2013-2017*

\begin{tabular}{|c|c|c|c|c|c|}
\hline Name of the FIE & $\mathbf{Y}$ & $\begin{array}{c}\text { Regression equation } \\
\mathrm{Y}=\mathrm{A}+\mathrm{B} X, \%\end{array}$ & $\mathbf{r}$ & $\mathbf{t}$ & $\mathbf{r}^{2}$ \\
\hline \multirow{3}{*}{$\begin{array}{l}\text { PJSC "Karlsberg } \\
\text { Ukraine" }\end{array}$} & $R O A$ & $18.63163+0.00012 x$ & 0.152 & 0.266 & 0.023 \\
\hline & $R O E$ & $10.82388+0.00217 \mathrm{X}$ & 0.846 & 2.754 & 0.717 \\
\hline & $R O S$ & $43.59190-0.00029 \mathrm{X}$ & -0.176 & -0.310 & 0.031 \\
\hline \multirow{3}{*}{ PJSC "Obolon" } & $R O A$ & $-56.03494+0.02322 \mathrm{X}$ & 0.539 & 1.109 & 0.291 \\
\hline & $R O E$ & $-233.16845+0.08535 X$ & 0.275 & 0.495 & 0.076 \\
\hline & $R O S$ & $66.76113-0.01509 \mathrm{X}$ & -0.915 & -3.940 & 0.838 \\
\hline \multirow{3}{*}{ PJSC "Kyivkhlib” } & $R O A$ & $9.68156-0.03532 \mathrm{X}$ & -0.657 & -1.509 & 0.431 \\
\hline & $R O E$ & $33.85275-0.12002 \mathrm{X}$ & -0.704 & -1.719 & 0.496 \\
\hline & $R O S$ & $23.74181+0.00344 X$ & 0.224 & 0.398 & 0.050 \\
\hline \multirow{3}{*}{$\begin{array}{l}\text { PJSC "Pologovsky } \\
\text { Oil Extraction } \\
\text { Plant" }\end{array}$} & $R O A$ & $1.12776+0.00008 X$ & 0.264 & 0.474 & 0.070 \\
\hline & $R O E$ & $5.18705+0.00020 X$ & 0.212 & 0.375 & 0.045 \\
\hline & $R O S$ & $17.67346-0.00010 \mathrm{X}$ & -0.321 & -0.588 & 0.103 \\
\hline \multirow{3}{*}{$\begin{array}{l}\text { Private JSC “APK- } \\
\text { INVEST" }\end{array}$} & $R O A$ & $-4.30831+0.00532 \mathrm{X}$ & 0.349 & 0.644 & 0.122 \\
\hline & $R O E$ & $11.89179+0.00163 X$ & 0.040 & 0.069 & 0.002 \\
\hline & $R O S$ & $0.05195+0.00616 X$ & 0.215 & 0.382 & 0.046 \\
\hline \multirow{3}{*}{$\begin{array}{l}\text { PJSC "Zhytomyr } \\
\text { Butter Factory" }\end{array}$} & $R O A$ & $11.63393+0.00302 X$ & 0.165 & 0.290 & 0.027 \\
\hline & $R O E$ & $12.99793+0.00812 \mathrm{X}$ & 0.403 & 0.762 & 0.162 \\
\hline & $R O S$ & $23.78787+0.00242 X$ & 0.397 & 0.749 & 0.158 \\
\hline \multirow{3}{*}{$\begin{array}{l}\text { PJSC "Kharkiv } \\
\text { Biscuit Factory" }\end{array}$} & $R O A$ & $20.13320-0.02847 X$ & -0.118 & -0.206 & 0.014 \\
\hline & $R O E$ & $20.53562-0.02323 X$ & -0.090 & -0.157 & 0.008 \\
\hline & $R O S$ & $21.84916-0.03504 \mathrm{X}$ & -0.524 & -1.066 & 0.275 \\
\hline \multirow{3}{*}{$\begin{array}{l}\text { PJSC "Dniprovsky } \\
\text { starch flour } \\
\text { combine" }\end{array}$} & $R O A$ & $6.80305-0.00593 \mathrm{X}$ & -0.657 & -0.870 & 0.431 \\
\hline & $R O E$ & $10.84164-0.00747 \mathrm{X}$ & -0.372 & -0.401 & 0.138 \\
\hline & $R O S$ & $7.69991-0.00601 X$ & -0.451 & -0.505 & 0.203 \\
\hline \multirow{3}{*}{$\begin{array}{l}\text { Private JSC "Kyiv } \\
\text { Confectionary } \\
\text { Factory "Roshen" }\end{array}$} & $R O A$ & $1.21434+0.00023 \mathrm{X}$ & 0.087 & 0.152 & 0.008 \\
\hline & $R O E$ & $1.66710+0.00054 \mathrm{X}$ & 0.127 & 0.222 & 0.016 \\
\hline & $R O S$ & $14.56597-0.00265 X$ & -0.815 & -2.436 & 0.664 \\
\hline \multirow{3}{*}{$\begin{array}{l}\text { PJSC "The house of } \\
\text { vintage cognacs } \\
\text { "Tauria" }\end{array}$} & $R O A$ & $11.04227-0.04066 \mathrm{X}$ & -0.620 & -1.369 & 0.385 \\
\hline & $R O E$ & $31.79628-0.11103 x$ & -0.606 & -1.319 & 0.367 \\
\hline & $R O S$ & $30.16522+0.05660 x$ & 0.303 & 0.551 & 0.092 \\
\hline \multirow{3}{*}{$\begin{array}{l}\text { PJSC Confec- } \\
\text { tionery Factory } \\
\text { "Kharkivyanka" }\end{array}$} & $R O A$ & $3.10429+0.01155 \mathrm{X}$ & 0.029 & 0.041 & 0.001 \\
\hline & $R O E$ & $9.57429-0.01425 \mathrm{X}$ & -0.014 & 0.020 & 0.000 \\
\hline & $R O S$ & $3.38143+0.01528 \mathrm{X}$ & 0.037 & 0.052 & 0.001 \\
\hline \multirow{3}{*}{$\begin{array}{l}\text { PJSC "Kremenchug } \\
\text { confectionery } \\
\text { factory" }\end{array}$} & $R O A$ & $0.63524-0.00221 X$ & -0.547 & -1.132 & 0.299 \\
\hline & $R O E$ & $1.61303-0.00518 x$ & -0.561 & -1.174 & 0.315 \\
\hline & $R O S$ & $8.51365+0.00070 \mathrm{X}$ & 0.138 & 0.242 & 0.019 \\
\hline \multirow{3}{*}{$\begin{array}{l}\text { PJSC "Sumy food } \\
\text { products factory" }\end{array}$} & $R O A$ & $-17.96081+0.30246 X$ & 0.542 & 1.117 & 0.294 \\
\hline & $R O E$ & $-41.18742+0.68167 X$ & 0.479 & 0.945 & 0.230 \\
\hline & $R O S$ & $5.98658+0.02400 \mathrm{X}$ & 0.104 & 0.181 & 0.011 \\
\hline
\end{tabular}

* Author's calculations based on official data [21]. It is marked here $\mathrm{r}$ - coefficient of pair correlation between $\mathrm{X}$ and $\mathrm{Y}, \mathrm{t}-\mathrm{t}$ - Student's criterion, $\mathrm{r}^{2}-$ coefficient of determination. 
We propose to analyze the correlation-regression calculations at first according to the coefficient of determination $\mathrm{r}^{2}$. Only three coefficients of determination correspond to the value of a regressive model of satisfactory quality: $\mathrm{r}^{2}=0.717$ (ROE, PJSC "Karlsberg Ukraine"); $\mathrm{r}^{2}=0.838$ (ROS, PJSC “Obolon"); $\mathrm{r}^{2}=0.664$ (ROS, Private JSC "Kyiv Confectionary Factory "Roshen"). If the coefficient of determination $r^{2}=0.838$ for PJSC "Obolon", this means that the variation in the ROS for $83.8 \%$ due to the variation in the insurance costs, the share of not taken into account other factors remains $16.2 \%$. That is, the cost of insurance determines the variance of the profitability of the listed enterprises, respectively for $71.7 \%, 83.8 \%$, and $66.4 \%$, which has a rather significant effect.

The lower values (the interval $\mathrm{r}^{2}$ for $0.1-0.5$ ) of the determination coefficient are fixed in nine cases: within the limits of the minimum value $r^{2}=0.103$ for $R O S$ to the PJSC "Pologovsky Oil Extraction Plant", and to the maximum $\mathrm{r}^{2}=0.496$ for $R O E$ to the PJSC "Kyivkhlib". The insurance costs determines the profitability and efficiency of such enterprises only by $10.3 \%$ and $49.6 \%$ respectively. In this case we can conclude that the proposed regression model is of low quality, and the share of insurance costs does not significantly affect the indicated performance indicators.

The least impact on insurance costs related for the others of the FIEs, where the determination coefficients $\mathbf{r}^{2}$ were less than 0.1 .

The density of the relationship between the investigated parameters of the regression equation, which is determined by the Pearson correlation coefficient $\mathbf{r}$, confirms the analysis results on the basis of the coefficient of determination $\mathbf{r}^{2}$. The analysis shows a direct proportional relationship between ROE and insurance costs for PJSC "Karlsberg Ukraine", and the inverse proportionality between ROS and insurance costs for PJSC "Obolon" and Private JSC "Kyiv Confectionary Factory "Roshen”.

\section{Analysis of the impact of insurance costs share on profitability}

Let X share of insurance costs $S_{1}$ (table 4), and the target function of the analysis (dependent variable Y) - profitability indicators $R O A, R O E$, ROS (table 1). Let perform a hypothesis test for this case. Equation of pair linear regression was constructed in the form of dependence $\mathrm{Y}=\mathrm{A}+\mathrm{BX}$. The corresponding calculations are given in Table 6 .

Thus, the analysis confirms the second proposed hypothesis about the existence of a dependence between the competitiveness of the FIEs and the portion of money allocated to the insurance. This hypothesis can have confirmation for FIEs with high efficiency of doing business. 
Table 6

Indicators of correlation-regression analysis of profitability $(\mathrm{Y})$ and the share of insurance costs (X) for FIEs of Ukraine for 2013-2017*

\begin{tabular}{|c|c|c|c|c|c|}
\hline Enterprise & $\mathbf{Y}$ & $\begin{array}{c}\text { Regression equation } \\
\mathrm{Y}=\mathrm{A}+\mathrm{B} \mathrm{X}, \%\end{array}$ & $\mathbf{r}$ & $\mathbf{t}$ & $\mathbf{r}^{2}$ \\
\hline \multirow{3}{*}{$\begin{array}{l}\text { PJSC "Karlsberg } \\
\text { Ukraine" }\end{array}$} & $R O A$ & $28.14066-28.14617 X$ & -0.577 & -1.224 & 0.333 \\
\hline & $R O E$ & $35.04222-22.62293 \mathrm{X}$ & -0.147 & -0.257 & 0.022 \\
\hline & $R O S$ & $19.60638+71.60377 X$ & 0.729 & 1.846 & 0.532 \\
\hline \multirow{3}{*}{ PJSC “Obolon” } & $R O A$ & $-9.93574+47.79888 X$ & 0.073 & 0.127 & 0.005 \\
\hline & $R O E$ & $-68.84353+231.05093 X$ & 0.049 & 0.085 & 0.002 \\
\hline & $R O S$ & $12.38136+231.96806 \mathrm{X}$ & 0.924 & 4.182 & 0.854 \\
\hline \multirow{3}{*}{ PJSC “Kyivkhlib” } & $R O A$ & $9.00738-491.94399 \times$ & -0.761 & -2.035 & 0.580 \\
\hline & $R O E$ & $31.85167-1687.78418 \mathrm{X}$ & -0.824 & -2.523 & 0.680 \\
\hline & $R O S$ & $23.94915+40.15651 \mathrm{X}$ & 0.218 & 0.386 & 0.047 \\
\hline \multirow{3}{*}{$\begin{array}{l}\text { PJSC "Pologovsky } \\
\text { Oil Extraction } \\
\text { Plant" }\end{array}$} & $R O A$ & $0.87103+1.94349 X$ & 0.266 & 0.478 & 0.071 \\
\hline & $R O E$ & $4.50302+4.79535 X$ & 0.216 & 0.383 & 0.047 \\
\hline & $R O S$ & $17.50932-1.99752 X$ & -0.264 & -0.475 & 0.070 \\
\hline \multirow{3}{*}{$\begin{array}{l}\text { Private JSC } \\
\text { "APK-INVEST" }\end{array}$} & $R O A$ & $46.45545-313.86218 \mathrm{X}$ & -0.711 & -1.751 & 0.505 \\
\hline & $R O E$ & $94.41423-616.05769 \mathrm{X}$ & -0.520 & 1.055 & 0.271 \\
\hline & $R O S$ & $87.46645-585.70221 \mathrm{X}$ & -0.708 & -1.734 & 0.501 \\
\hline \multirow{3}{*}{$\begin{array}{l}\text { PJSC "Zhytomyr } \\
\text { Butter Factory" }\end{array}$} & $R O A$ & $19.63317-144.15929 X$ & -0.388 & -0.730 & 0.151 \\
\hline & $R O E$ & $23.85982-150.88496 \mathrm{X}$ & -0.368 & -0.686 & 0.135 \\
\hline & $R O S$ & $22.93319+45.92920 \mathrm{X}$ & 0.371 & 0.692 & 0.138 \\
\hline \multirow{3}{*}{$\begin{array}{l}\text { PJSC "Kharkiv } \\
\text { Biscuit Factory" }\end{array}$} & $R O A$ & $20.82708-370.06494 X$ & -0.349 & -0.645 & 0.122 \\
\hline & $R O E$ & $22.99409-415.90909 \mathrm{X}$ & -0.368 & -0.685 & 0.135 \\
\hline & $R O S$ & $13.10688+122.59740 \mathrm{X}$ & 0.416 & 0.793 & 0.173 \\
\hline \multirow{3}{*}{$\begin{array}{l}\text { PJSC "Dniprovsky } \\
\text { starch flour } \\
\text { combine" }\end{array}$} & $R O A$ & $9.35890-48.35527 \mathrm{X}$ & -0.890 & -1.951 & 0.792 \\
\hline & $R O E$ & $17.49195-83.37520 \mathrm{X}$ & -0.691 & -0.955 & 0.477 \\
\hline & $R O S$ & $11.99398-60.13525 \mathrm{X}$ & -0.750 & -1.135 & 0.563 \\
\hline \multirow{3}{*}{$\begin{array}{l}\text { Private JSC "Kyiv } \\
\text { Confectionary } \\
\text { Factory "Roshen" }\end{array}$} & $R O A$ & $-2.08845+9.86740 \mathrm{X}$ & 0.601 & 1.304 & 0.362 \\
\hline & $R O E$ & $-3.81466+16.83396 \mathrm{X}$ & 0.636 & 1.429 & 0.405 \\
\hline & $R O S$ & $14.96441-8.74069 \mathrm{X}$ & -0.429 & -0.822 & 0.184 \\
\hline \multirow{3}{*}{$\begin{array}{l}\text { PJSC "The house } \\
\text { of vintage cognacs } \\
\text { "Tauria" }\end{array}$} & $R O A$ & $4.97292-11.53429 X$ & -0.320 & -0.584 & 0.102 \\
\hline & $R O E$ & $15.87963-35.90908 X$ & -0.356 & -0.660 & 0.127 \\
\hline & $R O S$ & $29.30725+78.43663 X$ & 0.763 & 2.043 & 0.582 \\
\hline \multirow{3}{*}{$\begin{array}{l}\text { PJSC “Confec- } \\
\text { tionery Factory } \\
\text { "Kharkivyanka" }\end{array}$} & $R O A$ & $10.64353-188.35043 \mathrm{X}$ & -0.656 & -1.228 & 0.430 \\
\hline & $R O E$ & $27.12598-518.76875 \mathrm{X}$ & -0.721 & -1.471 & 0.520 \\
\hline & $R O S$ & $11.70500-203.00710 \mathrm{X}$ & -0.682 & -1.318 & 0.465 \\
\hline \multirow{3}{*}{$\begin{array}{l}\text { PJSC "Kremen- } \\
\text { chug confectionery } \\
\text { factory" }\end{array}$} & $R O A$ & $0.77378-3.50596 \mathrm{X}$ & -0.704 & -1.717 & 0.496 \\
\hline & $R O E$ & $1.85433-8.01426 \mathrm{X}$ & -0.705 & -1.720 & 0.497 \\
\hline & $R O S$ & $9.07599-0.34630 \mathrm{X}$ & -0.056 & -0.096 & 0.003 \\
\hline \multirow{3}{*}{$\begin{array}{l}\text { PJSC "Sumy food } \\
\text { products factory" }\end{array}$} & $R O A$ & $-4.95702+14.54509 x$ & 0.645 & 1.463 & 0.416 \\
\hline & $R O E$ & $-12.13850+34.10277 \mathrm{X}$ & 0.594 & 1.278 & 0.352 \\
\hline & $R O S$ & $6.84205+2.05496 \mathrm{X}$ & 0.220 & 0.390 & 0.048 \\
\hline
\end{tabular}

*Author's calculations based on official data [21]. It is marked here $\mathrm{r}$ - coefficient of pair correlation between $\mathrm{X}$ and $\mathrm{Y}, \mathrm{t}-\mathrm{t}$ - Student's criterion, $\mathrm{r}^{2}$ - coefficient of determination. 


\section{Conclusions}

The paper has analyzed the dynamics and structure of insurance costs and tests hypotheses concerning the impact of insurance on the efficiency of the activity of the insurance company, and also the role of insurance was explored to improve the security of the food market. The study describes the indicators of the efficiency and competitiveness of FIEs of Ukraine during 2013-2017.

The analysis confirms the hypothesis that FIEs with higher competitiveness are more prone to insurance. The hypothesis about the existence of a dependence between the competitiveness of FIEs and the portion of money allocated by FIEs for insurance is confirmed only for FIEs with high efficiency of doing business.

The results of the study are summarized by the following conclusions:

1. The analysis showed that the investigated FIEs do not violate the norms of the current antimonopoly legislation of Ukraine.

2. Among the selected list of food industry enterprises, the largest market share and share in the food industry as well as in Ukraine's GDP has PJSC "Karlsberg Ukraine". The share of the company in the market is $1.173 \%$ of the food industry and $0.220 \%$ of Ukraine's GDP.

3. High performance and profitability indicators were related to the PJSC "Karlsberg Ukraine". At the same time for PJSC "Obolon", PJSC "Kyivkhlib", PJSC "Sumy food products factory", PJSC "Pologovsky Oil Extraction Plant" and for PJSC "Kremenchug confectionery factory" these indicators for some periods could be regarded as indicators of loss.

4. The low value of the profitability of the food industry enterprises of Ukraine can be explained both by internal factors and external problems.

5. Insurance costs insignificantly change the total production costs and, consequently, moderately affect the formation of the profit of the FIEs: the largest share of insurance costs $2.173 \%$ was for PJSC "Pologovsky Oil Extraction Plant" in 2016.

6. The rates of change of the insurance costs for FIEs during 2013-2017 were in range from $-99.6 \%$ (PJSC "The house of vintage cognacs "Tauria"), and to $881.4 \%$ (PJSC "Pologovsky Oil Extraction Plant") in 2014-2015.

7. The analysis does not fully confirm the hypothesis that "the main players in the food industry with a higher competitiveness are more prone to insurance".

8. The hypothesis of the existence of a relationship between the competitiveness of the FIEs and the part of the money allocated to the insurance business can only be confirmed for FIEs with high-efficiency business case.

9. Result of the study the use of insurance as a tool to increase food market security confirms its high efficiency.

Acknowledgements. The results of the study were obtained within the framework of the state budget research funding of the Department of Finance of the National University of Food Technologies "Comprehensive assessment and ways to increase the competitiveness of Ukraine's insurance market in the context of European integration". State registration number 0117U001246. Order of the Ministry of Education and Science of Ukraine №198 from 10.02.2017 for 2017-2019. Research Manager - Doctor of Economic Sciences, Professor, Lada Shirinyan). 


\section{References}

1. Akinrinola O.O., Okunola A.M. (2014), Effects of Agricultural Insurance Scheme on Agricultural Production in Ondo State, MPRA Paper, 74558.

2. Spörri et al. (2012), The Impact of Crop Insurance on the Economic Performance of Hungarian Cropping Farms, EAAE Seminar "Price Volatility and Farm Income Stabilisation", 123, Dublin.

3. Juan H. et al. (2016), Estimating the Effect of Crop Insurance on Input Use When Insured Farmers are Monitored, Agricultural \& Applied Economics Association Annual Meeting, Boston, Massachusetts.

4. Zhao Y., Preckel P. (2016), An empirical analysis of the effect of crop insurance on farmers' income, China Agricultural Economic Review, 8(2), pp. 299-313.

5. Kim Y., Pendell D.L., Yu J. (2018), Effects of Crop Insurance on Farm Disinvestment and Exit Decisions, Available at: https://arefiles.ucdavis.edu.

6. Jisang Yua J., Sumnerb D.A. (2017), Effects of subsidized crop insurance on crop choices, Agricultural Economics, 49, pp. 533-545.

7. Bachev H. (2012), Risk Management in the Agri-food Sector, Contemporary Economics, 7(1), pp. 45-62.

8. Lorant A., Farkas M.F. (2015), Risk management in the agricultural sector with special attention to insurance, Polish Journal of Management Studies, 11(2).

9. Baeva V.V. (2015), Metodychni pidkhody do upravlinnya konkurentospromozhnistyu pidpryyemstva kharchovoyi promyslovosti, Visnyk KHNAU im. V.V. Dokuchayeva, 3, pp. 349-361.

10. Pylypenko V.V., Pylypenko N.M. (2016), Naukovo-praktychni aspekty silskohospodarskykh pidpryyemstv, Visnyk Sumskoho natsionalnoho ahrarnoho universytetu, 1(67), pp. 73-78.

11. Legeza D.G. (2011), Metodyka rehresoskopichnoyi silskohospodarskoyi produktsiyi na rivni rehionu, Formuvannya rynkovoyi ekonomiky, 2, pp. 248-256.

12. Cherednichenko O.O. (2013), Otsinka konkurentospromozhnosti produktsiyi silskohospodarskykh pidpryyemstv molochnoyi haluzi, Naukovyy visnyk Natsionalnoho universytetu bioresursiv ta pryrodokorystuvannya Ukrayiny: Ekonomika, ahrarnyy menedzhment, biznes, 181(6), pp. 237-245.

13. Tycholyz L.S. (2013), Analiz ta otsinka konkurentospromozhnosti silskohospodars'kykh pidpryyemstv, Zbirnyk naukovykh prats Podilskoho derzhavnoho ahrarno-tekhnichnoho universytetu, 21, pp. 256-260.

14. Irytytsheva I.O. (2012), Stratehichni oriyentyry rozvytku kharchovoyi promyslovosti Ukrayiny v hlobalizatsiyi, AHROSVIT, 12, pp. 32-34.

15. Vasilchenko K.G. (2013), Stan, problemy ta perspektyvy rozvytku innovatsiynoyi diyalnosti v kharchoviy promyslovosti Ukrayiny, Stratehiya ekonomichnoho rozvytku Ukrayin, 33, pp. 166-173.

16. Kvasko A.V. (2017), Analiz metodiv kontrolyu konkurentsiyi pidpryyemstva, Scientific Papers, 1(54), pp.111-118.

17. Buracek I.V., Bilenchuk O.O. (2016), Konkurentospromozhnist produktsiyi pidpryyemstv: sutnist, metodyka ta metodyka, Hlobalni ta natsionalni problemy ekonomiky, 14, pp. 288-293.

18. Shwed T.V., Bila I.S. (2017), Otsinka konkurentospromozhnosti pidpryyemstva, Ekonomika i Suspilstvo, 8, pp. 405-410. 
19. The Law of Ukraine "On Protection of Economic Competition" with amendments and additions], Holos Ukrayiny - Voice of Ukraine, 37, Available at: http://zakon3.rada.gov.ua/laws/show/2210-14.

20. Porter M. (2001), Competition: study. pos., M. Williams, 425p.

21. Ahentstvo $\mathrm{z}$ rozvytku infrastruktury fondovoho rynku Ukrayiny, Available at: http://smida.gov.ua.

22. Derzhavna sluzhba statystyky Ukrayiny, Available at: http://www.ukrstat.gov.ua/.

23. Novotenko et al. (2016), Perspektyvy rozvytku kharchovoyi promyslovosti Ukrayiny, Hlobalni ta natsionalni problemy ekonomiky, 11, pp. 454-460.

24. Semenenko O.H. (2017), Analiz rozvytku kharchovoyi promyslovosti Ukrayiny, Ekonomichnyy visnyk universytetu: Ekonomika ta upravlinnya, 33(1), pp. 168-182.

25. Topiy I.I. (2014), Suchasnyy stan i perspektyvy rozvytku kharchovoyi promyslovosti Ukrayiny, Visnyk Universytetu bankivskoyi spravy Natsional'noho banku Ukrayiny, 2(20), pp. 46-49.

26. Ambrosov V. (2013), Rynok i stratehiya rozvytku silskohospodarskykh pidpryyemstv, Ekonomika APK, 10, pp. 72-79.

27. Arych M., Shirinyan L. (2017), Doslidzhennya konkurentospromozhnosti strakhovoho rynku Ukrayiny: heohrafichnyy analiz, Scientific works of NUKHT, 23(5), pp. 17-25.

28. Blagun I. (2012), Kontseptualni zasady formuvannya konkurentnoyi stratehiyi pidpryyemstva, Rehionalna biznes-ekonomika ta upravlinnya, 3(15), pp. 3-11.

29. Hubar O.V. (2015), Konkurentospromozhnist' kharchovoyi promyslovosti Ukrayiny v umovakh yevrointehratsiynykh protsesiv, Economics Bulletin, 4, pp. 82-87.

30. Demyanenko M.Ya. et al. (2008), Otsinka kredytospromozhnosti ahroformuvan' (teoriya ta praktyka): monohrafiya, NNT IAE, Kyiv, 302 p.

31. Kvasha S.M. and Hryhoryev S.O. (2016), Sutnist ta osoblyvosti ahrarnoho rynku. Visnyk Odeskoho natsionalnoho universytetu. Seriya: Ekonomika, 21(8), pp.56-59.

32. Natsionalna komisiya, shcho zdiysnyuye derzhavne rehulyuvannya u sferi rynkiv finansovykh posluh Ukrayiny, Available at: http://www.dfp.gov.ua

33. Sabluk P.T. (2013), Finansove zabezpechennya rozvytku ahrarnoho sektoru Ukrayiny, Ekonomika APK, 7, pp. 142-143.

34. Yaktsovy D.V. (2013), Suchasni metodyky otsinky konkurentospromozhnosti pidpryyemstva. Visnyk sotsialno-ekonomichnykh doslidzhen, 4(51). pp. 183-188.

35. Anton J. (2009), Managing Risk in Agriculture: A Holistic Approach, OECD Publishing, Paris.

36. Aubert M., Enjolras G. (2018), Does crop insurance lead to better environmental practices? Evidence from French farms, Conference, Vancouver, British Columbia, International Association of Agricultural Economists.

37. Cornaggia J. (2013), Does risk management matter? Evidence from the U.S. agricultural industry, Journal of Financial Economics, 109(2), pp. 419-440.

38. Fadhliani Z. (2016), The Impact of Crop Insurance on Indonesian Rice Production, Theses and Dissertations, 1723.

39. Goral J., Wigier M. (2017), Risk in the food economy - theory and practice, Institute of Agricultural and Food Economics National Research Institute.

40. Olubiyo S.O., Hill G.P., Webster J.P. (2009), Econometric analysis of the impact of agricultural insurance on farming systems in the Middle Belt, Nigeria, African Journal of Food, Agriculture, Nutrition and Development, 9 (6).

41. Ramiro I. (2009), Agricultural Insurance, Primer Series on Insurance, 12. 
42. Shawn A. Cole, Wentao Xiong (2017), Agricultural Insurance and Economic Development, Annual Review of Economics, 9, pp. 235-262.

43. Tarasov A. (2011), Coherent Quantitative Analysis of Risks in Agribusiness: Case of Ukraine, Agris on-line Papers in Economics and Informatics, III.

44. Yulia Nesterchuk, Olena Prokopchuk, Yuriy Tsymbalyuk, Oleksandr Rolinskyi, Yuriy Bilan (2018), Current status and prospects of development of the system of agrarian insurance in Ukraine, Investment Management and Financial Innovations, 15(3), pp. 56-70.

45. Isaboke H.N., Zhang Q., Nyarindo W.N. (2016), The effect of weather index based micro-insurance on food security status of smallholders, Agricultural and Resource Economics: International Scientific E-Journal, 2(3), Available at: www.arejournal.com.

46. Bogdan Mârzaa, Carmen Angelescub, Cristina Tindecheb (2015), Agricultural Insurances and Food Security. The New Climate Change Challenges, Procedia Economics and Finance, 27, pp. 594-599.

47. How can we make insurance work for food security? Conference Report, Agricultural Insurance Conference, Berlin.

48. Marianna Lysenko (2014), The problem of ensuring the economic security of dairy industry in Ukraine, Economics \& Sociology, 7(2), pp. 16-171

49. Postanova Kabinetu Ministriv Ukrayiny "Pro stvorennya Yedynoho derzhavnoho reyestru pidpryyemstv ta orhanizatsiy Ukrayiny", Available at: https://zakon.rada.gov.ua/laws/show/118-96-\%D0\%BF?lang=en.

50. Yedynyy derzhavnyy reyestr pidpryyemstv ta orhanizatsiy Ukrayiny (YEDRPOU), Available at: http://kyivobl.ukrstat.gov.ua/content/p.php3?c=37\&lang=1. 